\title{
Regulation of Air Freight Pickup and Delivery
}

Air transportation is presently the fastest growing mode of freight transportation. The imminent introduction of cargo aircraft with capacities of up to 100 tons and greatly lowered operating costs will spur this growth. But efficiencies achieved in air cargo operations can be lost if ground transportation between the shipper and the airport is unduly expensive or time consuming. Here the key lies with the Interstate Commerce Commission. Normally motor vehicle movement of property in interstate commerce is subject to Commission reguiation. But Commission authority over air cargo pickup and delivery service is limited by section 203(b)(7a) of the Interstate Commerce Act, which exempts from Commission economic regulation motor vehicle transportation "incidental to transportation by aircraft." 1 By its narrow understanding of "incidental" the Commission has extended its own jurisdiction while hampering the development of efficient ground transportation for air cargo services.

The significance to the shipper of the incidental-to-air exemption lies in the ability of carriers operating under the exemption to provide more comprehensive service, specialized to the needs of air cargo operations, than can the ordinary, Commission-regulated, general commodities motor carrier. The exempt carrier is not required to possess a certificate of public convenience and necessity." This frees him from time-consuming applications for operating rights, which are normally met by strong opposition from existing carriers. ${ }^{3}$ Moreover, because the carrier is not tied to a particular route or area by a certificate,

1. 52 Stat. 1029 (1938); 49 U.S.C. $\$ 303(b)(73)$ (1964). The section provides that nothing in Part II (providing for motor carrier regulation) of the Interstate Commerce Act (hereinafter "the Act")

except the provisions of section 204 relative to qualifications and maximum hours of service of employees and safety of operations or standards of equipment shall be construed to include... (7a) the transportation of persons or property by motor vehicle when incidental to transportation by aircraft.

2. See section 203(c) of the Act, 71 Stat. 411 (1957), 49 U.S.C. $\$ 303(c)$ (1964); and sections 206(a) and 209(a), 49 Stat. 551, 552 (1935), 49 U.S.C. $\$ \S 306(a)(1), 309$ (a)(1) (1964). Section $222($ a) of the Act provides for a penalty of up to $\$ 500$ per day for operstion without a common carrier certificate or a contract carrier permit. 49 Stat. 504 (1935), 49 U.S.C. § 322(a) (1964).

3. Section 1.247 (d) of the General Rules of Practice of the ICC, 31 FED. REC. 9926-27 (1966), provides that any person with operating rights "in conflict with that sought" by an applicant for new authority may protest such applications. It scems clear that the Commission may deny an application for operating rights even in the absence of protest from existing carriers, on the grounds that applicant has failed to show that the proposed service is required by the public convenience and necessity. Sce, c.g., ICC v. Parker, 326 U.S. 60, 65 (1945). 
he is free to adjust quickly to changes in customer location or to the appearance of new markets, both of which may happen suddenly in the fast-growing air cargo industry. ${ }^{4}$ The exemption of the carrier from the Commission's power to prescribe rate levels frees him to reflect cost changes in his rate structure without first filing the rate changes with the Commission, where they would be subject to Commission scrutiny, to objection by competing carriers, and potentially to suspension and investigation. ${ }^{5}$

This flexibility permitted by the exemption is valuable to air cargo users, because rapid changes in aviation technology and changes in the organization and scheduling of production by shippers may result in radical shifts in the pattern of demand for air cargo over short periods. Because air transportation is a premium service, used instead of other forms of transportation primarily because of its speed, many air cargo shipments will be of a quasi-emergency character. If a carrier operating under the exemption is available, the shipper need not spend the time seeking a regulated carrier authorized to carry the particular commodity over the particular route involved. Nor need the shipper worry whether the carrier appreciates the necessity for arrival of the shipment at the airport in time to meet departing flights.

The legislative history of section 203(b)(7a) gives no explicit guidance for the interpretation of the exemption..$^{6}$ The Commission's position is that "motor transportation is 'incidental' to transportation by air when that motor transportation is limited to a bona fide collection, delivery, or transfer service within a reasonable terminal area of the air carrier." $\tau$ The phrase "service within a reasonable terminal area"

4. The Commission is normally unwilling to grant changes in the services authorized by certificates of public convenience and necessity in order to follow the traffic. Sec, e.g., Smith \& Solomon Trucking Co., 61 M.C.C. 748, 752 (1953), afj'd, 120 F. Stupp. 277 (D.N.J. 1954).

5. Section 216(e) of the Act empowers the Commission to fix rates, 49 Stat. 558 (1935), 49 U.S.C. $\$ 316(\mathrm{e})$ (1964). Section $216(\mathrm{~g})$ permits suspension of any tariff or rate on complaint of any interested party or upon the Commission's own initiative, and section 217 requires carriers to file and adhere to published tariffs. 49 Stat. 559, 560 (1935), 49 U.S.C. \$\$ 316(g), 317 (1964).

6. Section 203(b) (7a) was added to the Act by the Civil Aeronautics Act of 1938, and the published legislative history of that statute is devoid of any clarification of thic exemption. Civil Aeronautics Act of 1938, § 1107(j), 52 Stat. 1029 (1938). This section was added to the Act in conference, and no mention of it appears to have been made in the floor debates upon the bill. The report of the House conferees only stated:

The conference agreement follows the provisions of the House amendment with the following exceptions; .... (2) the Motor Carrier Act, 1936 [sic], is amended so as to render its provisions inapplicable (with certain specified exceptions) to the transportation of persons or property by motor vehicle when incidental to transportation by aircraft.

H.R. REP. No. 2635, 75th Cong., 3d Sess. 81 (1938).

7. Hazel Kenny, 61 M.C.C. 587,595 (1953). A similar statement applicable to passenger 
is in turn used by the Commission to refer to "service which supplements and combines with line-haul service" and which "is essentially intra-community in character." 8 Under this definition, motor vehicle service which is "intercommunity service . . . falls outside the partial exemption of section 203(b)(7a)." This restriction to "intra-community" service is warranted neither by the context of the exemption within the Interstate Commerce Act nor by the economic characteristics of air transportation. ${ }^{10}$

\section{Development of ICG Control}

When the Commission first considered the exemption, in a 1941 series of cases involving Railway Express use of motor vehicles, it introduced without elaboration the belief that "incidental to transportation by aircraft" did not include intercommunity traffic. Because Railway Express provides ground pickup and delivery services for Air Express shipments, ${ }^{11}$ the Commission had to decide whether Railway Express required specific authority to transport Air Express shipments by motor vehicle, or whether it could provide the Air Express services under the shield of the $203(\mathrm{~b})(7 \mathrm{a})$ exemption. In two practically identical decisions (typical of others in the series), the Commission ruled that movements by road of 12 and 15 miles between the towns affected and the nearest airport city were not "incidental" to air transportation,

transportation is found in Motor Transportation of Passengers Incidental to Transportation by Aircraft, 95 Mr.C.C. 526, 533 (1964).

8. Zantop Air Transport, Inc, 102 M.C.C. 457, 461 (1960), quoting Commercial Zones and Terminal Areas, 54 M.C.C. 21, 63 (1952) (decision establishing geographic limits of surface freight forwarder and inter-city motor carrier terminal areas).

9. Zantop Air Transport, Inc, 102 M.C.C. 457, 462 (1960) (the Commission ruled that transportation by motor vehicle of property having a prior or subsequent movement by air, between TWilmington Airport and Baltimore is line-haul for-hire transportation by motor vehicle not within the 203(b)(7a) exemption).

10. This note concentrates upon objections to Commission interpretation of section 203(b)(7a) as it has been applied to transportation of property incidental to transportation by aircraft. For a large proportion of air travelers, the transportation to and from airports takes on more social significance than economic significance ("bon vojage" or "welcome" motivations induce friends or relatives to provide transportation). For many others exempt transportation is readily available because the commission has decided that passengers when flying interstate to an airport are not moving in interstate commerce when they purchase airport limousine service to an ultimate destination within the state in which the airport is located. See Motor Transportation of Passengers Incidental to Transportation by Aircraft, 95 M.C.C. 526, 536 (1964). Only if the passenger were holding a through ticket, covering at once the interstate air and the intrastate motor transportation, would the Commission consider whether or not the intrastate limousine service were within the incidental-to-air exemption. Ibid. Narrow interpretation of the exemption therefore has a much greater effect upon air cirgo than upon air passengers.

I1. The exclusive role of Railway Express in the provision of Air Express servicesas distinct from general air freight-is discussed in Air Freight Forwarder Case, 9 C.A.B. 473, $476-90$ (1948). See generally Wilson, Air Freight and Air Express, 15 LAw \& Costeur. Prob. 37 (1950). 
and required specific authority. ${ }^{12}$ No discussion or further reasoning was given..$^{13}$

After World War II, the boom in air cargo caused many firms to seek to operate air cargo collection and distribution services under the shield of the exemption. ${ }^{14}$ In the first major case of this period, Sky Freight Delivery Service, Inc., ${ }^{15}$ the Commission held that although the distances involved were greater than those in the earlier Railway Express cases, extensive geographic coverage alone could not defeat the exemption.

In determining whether a movement by motor is "incidental" to a prior or subsequent movement by air or is in fact an independent connecting carrier service, distance alone is not a controlling consideration, and this is particularly true in the area around New York City. ${ }^{10}$

In subsequent decisions, however, the Commission made it clear that to be within the exemption, service must be (with the exception of emergencies when mechanical failure or weather conditions make flying impossible) intracommunity collection, delivery, or transfer service. ${ }^{17}$ In the 1953 Hazel Kenny case, the Commission held that,

12. Railway Express Agency, Inc., 31 M.C.C. 332 (1941) (12 miles); Railway Express Agency, Inc., 31 M.C.C. 385,390 (1941):

... applicant's transportation of air express shipments by motor vehicle between Providence and Bristol, a distance of 15 miles, constitutes a line-haul operation. Such transportation is not considered to be "incidental to transportation by aircraft" within the meaning of the exemption provisions. Therefore, applicant requircs authority from us for its transportation of air-express shipments, moving in interstate or foreign commerce, between these points.

13. One of the three Commission members who decided both cases, stated without discussion that 203(b)(7a) should not be interpreted to require certification of Railway Express for the motor carriage of shipments with prior or subsequent movement by air. 31 M.C.C. 385,391 (1941); 31 M.C.C. 332, 336 (1941).

14. The post-war development of air cargo service is discussed in Durham \& Feldstcin, Regulation as a Tool in the Development of the Air Freight Industry, 34 V.. L. REv. 769, $770-76$ (1948).

15. 47 M.C.C. 229 (1947). Sky Freight sought common carrier authority for air cargo ground services in the New York area, or, in the alternative, exemption from the certification requirement under 203(b)(7a). Because there are no statutory provisions or Com. mission rules providing for the claim of exempt status under 209(b)(7a), the normal practice for firms wishing to operate motor transport of persons or property in connec. tion with air transportation is to apply for a common carrier certificate, suggesting, in the process, that the Commission should dismiss the application because the proposed service falls under the 203(b)(7a) exemption. The alternative is operation without appli. cation for a certificate and the risk of subjecting oneself to Commission enforcement proceedings for operating non-exempt service without a certificate of public convenience and necessity.

16. Id. at 241 .

17. In a 1948 case, the Commission recognized that "sporadic and irregular" cmergency operations were incidental to transportation by aircraft, but commented that normally, "when a motor service ... becomes in effect an interterminal or intercity service it can no longer be . . . merely 'incidental' or subordinate . . . but . . . must be looked upon as an independent line-haul service." Theodore Edward Graff, 48 M.C.C. 310,315 (1948). Subsequent cases have recognized the continuing vitality of the emergency transportation rule, e.g., Cyril P. Michaud, 73 M.C.C. 677 (1957). 
except for emergency service, the equation of "incidental" to intracommunity terminal area service was the only permissible interpretation of the exemption. ${ }^{18}$ The Commission, however, chose not to provide fixed mileage limits to the area about each airport in which pickup and delivery service could be provided. ${ }^{19}$ Instead, it ruled that the exemption would apply only for shipments moving on a through air bill of lading, with both the pickup and delivery points contained in existing air carrier tariffs for pickup and delivery service."0 Because the Civil Aeronautics Board had for some years limited air carrier pickup and delivery service tariffs to a maximum of 25 miles from airports (except for major cities like N'ew York), the Commission action effectively limited the exemption to a maximum 25 mile radius. This rule was upgraded to a Commission regulation in Motor Transportation of Property Incidental to Transportation by Aircraft, decided in $1964 .{ }^{21}$

This tying of the exemption to air carrier tariffs on file with the Civil Aeronautics Board had the virtue of providing the Commission with a simple dividing line between exempt and non-exempt service. Its vices were two. First, the tie to the air carrier tariffs creates an aura of external sanction for the limitation. But the CAB's limitation upon the extent of air carrier pickup and delivery tariffs has no relation to

18. Hazel Kenny, 61 M.C.C. 587, 595 (1953) (report of the Commission on further hearing). This decision reversed an earlier decision of the Commission, reported at 49 M.C.C. 182 (1949), in which Kenny had been held to possess the right to operate air cargo collection and distribution service up to fifty miles from Pittsburgh under the $203(\mathrm{~b})(7 \mathrm{a})$ exemption. The assertion on rehcaring that the only permissible interpretation of the exemption limited it to terminal areas was not accompanied by any discussion of the reasoning by which the Commission arrived at this conclusion.

19. 61 M.C.C. 587, $592-93$ (1953).

20. Id, at 595-96.

21. 95 M.C.C. 71 (1964), codified in 49 C.F.R. $\$ 210.40$ (1966 Supp.). I similar regu* lation was established for "incidental" transportation of passengers, Mlotor "Transporta. tion of Passengers Incidental to Transportation by Aircraft, 95 M.C.C. 520 (1901), 49 C.F.R. $\$ 210.45$ (1966 Supp.). "Incidental" passenger transportation was restricted to a flat twenty-five miles by the regulation. This was proinpted by the fact that paesenger are normally ticketed by the airlines only from airport to airport, and tiey armange their own transportation to and from airports. See discussion, supra note 10 . Airline tariffs therefore make no provision for radius of passenger collection and deliver service around the airports, and the Commission's regulation could not tie the limits of exempt passenger transportation to the published tarifts of the airlines.

This rule-making proceeding was prompted by a temporary aberration of Division One of the Commission from earlier decisions construing 203(b)(7a). The Division held in a 1962 certification proceeding that:

. . it follows logically from a consideration of the language in section 203(b)(7a)

that whenever a limousine ... transports an air passenger to or from the airport terminal as part of the passenger's continuing move from origin to destinstion, such transportation is a livery service provided for the use of passengers of airlines and is clearly dependent upon and incidental to such air service.

The Hatom Corp., 88 M.C.C. 653, 656-57 (1962) (2-1 decision). This decision wals promptly reversed by the whole Commission, The Hatom Corp., 91 II.C.C. 725 (1962). 
the incidental-to-air exemption. ${ }^{22}$ In fact, the $C A B$ has specifically indicated that its control over these tariffs does not represent an attempt to define the extent of the exemption. ${ }^{23}$ Therefore there is nothing about the CAB's limitation which requires the Commission to use it to define the limits of incidental-to-air transportation. Second, the tie to air carrier tariffs has no consistent relation to the principle that the exemption does not extend to "interterminal" or "intercity" service. If the principle is that "intercity . . . independent line-haul service" is not exempt, ${ }^{24}$ then the use of air carrier tariffs on file with the Civil Aeronautics Board is but an arbitrary substitute, and a poor one, for reasoned application of the rule.

The use of air carrier tariffs to define "incidental to transportation by aircraft" leads to odd results. Business $A$, within a town generating a high volume of air cargo, receives regular air cargo pickup and delivery service in accordance with published airline tariff provisions. The owner of business $B$, across the street in a different jurisdiction, cannot flag down the truck with a shipment bound for the same airport, the same airline, and the same final destination unless the airline has included B's town in its pickup and delivery tariff. And if B and other potential shippers in his town have little occasion to use air transport, the airlines may not care to incur the costs of asking the Board to extend the coverage of its pickup and delivery tariffs or of including and maintaining additional tariff entries. The use of "incidental" to distinguish between two parties so similarly situated seems indefensible.

The 1964 Motor Transportation of Property decision recognized the potential incompatibility of the air carrier tariff rule and the intercommunity-intracommunity distinction by providing for proceedings before the Commission to determine whether any particular point

22. The $\mathrm{CAB}$ limitation applies only to collection and distribution service provided when the airlines have seen fit to arrange in advance, through tariff publication, to provide service to the points in question.

The $\mathrm{CAB}$ has demonstrated in several instances that it has no inherent bias against ground services provided over distances much greater than 25 miles. Sec Flying Tiger Line, Inc., 30 C.A.B. 242 (1959), affd sub nom. City of Philadelphia 1. CAB, 289 F.2d 770 (D.C. Cir. 1961) (the CAB permitted the discontinuance of the Flying Tiger Line's west coast cargo service from Philadelphia Airport in favor of motor vehicle scrvice providing connections with faster west coast service via Newark Airport). The CAB hals also permitted Emery Air Freight, in several recent cases, to provide pickup and delivery services for its air freight forwarding operations well over twenty-five miles from Detroit and Boston. See CAB Docket No. 15327, Application of Emery Air lireight for Authority to File Pickup and Delivery Tariff, in Traffic World, December 11, 1965, p. 130; and Law' Notor Freight, Inc. v: CAB, 364 F.2d 139 (1st Cir. 1966).

23. 29 Fed. Reg. 6275 (1964) (promulgating 14 C.F.R. \$ 222, "Air Cargo pickup and Delivery Zones").

24. Theodore Edward Graff, 48 M.C.C. 310, 315 (19.18). 
was actually within the limits of "incidental" service, regardless of its inclusion or non-inclusion in an air carrier tariff. ${ }^{26}$ It was plain that the Commission feared the appearance of air carrier pickup and delivery tariffs which, under past Commission standards, would clearly involve intercommunity transportation. 20

Such a case arose almost immediately when Zantop Air Transport, a supplemental cargo carrier, was charged with engaging in illegal line-haul motor transportation. ${ }^{27}$ Zantop had been transporting in its own vehicles, from Wilmington Airport to Baltimore, shipments with an immediately prior air movement from Detroit. Because Zantop was apparently operating within the limits of its tariffs on file with the Civil Aeronautics Board, ${ }^{28}$ the Commission was faced with a case in which it could not rely on the air carrier tariffs to exclude the service from the exemption. ${ }^{20}$ To find that the service was not "incidental" the Commission reverted to the 25-mile limit and argued that this limit could not be enlarged to include within the exemption any area characterizable as a "separate and distinct community."so

Thus, at present, service which can be classified as intercommunity service cannot be "incidental to transportation by aircraft" and cannot come within the exemption, whether or not the places involved are included in air carrier pickup and delivery tariffs. Exempt service can only be that bona fide pickup, delivery, or transfer service which is provided within the particular community-consisting of a core city and its environs-in which the airport is located.31 All other ser-

25. 95 M.C.C. 71 (1964), 49 G.F.R. $\$ \$ 210.40$ (c), 210.45(c) (1966 Supp.).

26. The Motor Transportation of Property decision made it clear that the Commission was relinquishing no control over the exemption by tying it in the first instanoe to the airline-published pickup and delivery tariffs. In order to make the new rule "consistent with our statutory responsibility to insure that transportation. . . exempt under ecction $203(b)(7 a)$ is truly "incidental"," the Commission provided that "a proceeding may be instituted looking toward the definition of the geographical exicnt of the 203(b)(7a) exemption at a particular point." 95 M.C.C. at 87. (Emphasis added.)

27. Zantop Air Transport, Inc, 96 M.C.C. 18 (1964).

28. Zantop was not using highway operations to provide air cango service to a city which it was not permitted to serve. See the second Zantop case, 102 M.C.C. 457, 458-59 (1966). Thus Zantop was probably operating literally within the terms of the 1964 I.C.C. regulation, in the sense that it was not providing pickup and delivery service bejond the limits within which the C.A.B. had authorized it to provide such service.

29. This was in contrast to cases like Hazel Kenny, 61 M.C.C. 587 (1953), in which the Commission limited the motor vehicle operator to direct air carrier tarifis currently on file for the Pittsburgh area.

30 . 96 M.C.C. at $22-23$ (1964). The reasoning is from the report of the joint board which investigated the alleged violation, but the board's report was adopted by the Commission as its own. Id. at 19. Zantop appealed the Commission decision, Zantop Air Transport, Inc. v. United States, 250 FSupp. 623 (E.D. Mich. 1965), and the court remanded the case for failure to show findings of fact. On reconsideration, the full Commission, one member dissenting, reaffirmed its decision, Zantop Air Transport, Inc, 102 M.C.C. 457 (1966).

31. See, e.g., 102 M.C.C. 457,462 (1966). ("Our concern, and the concern of the exemp- 
vice involving cargo with prior or subsequent movement by air is linehaul service subject to Commission economic regulation.

The Commission has yet to present any persuasive argument that 203(b)(7a) was intended to exempt only service between the airport and the city with reference to which the airport was constructed. The Commission has consistently maintained that the exemption applies only to bona fide terminal area service-that is, intracommunity service-but has nullified that principle in all those cases in which air carrier tariffs are on file, covering service within 25 miles of airports. The only evidence which the Commission has adduced to justify the limitation of the exemption to intracommunity service is a false analogy with another section of the Act.

\section{Arguments from the Statutes: Analogies Proper and Improper}

The Commission asserted in Zantop that the exemption is intended solely to insure "that each city have bona fide collection and delivery service to and from its designated airports." 32 This narrow view of the exemption's purpose appears to stem at least in part from the Commission's claim that the exemption is analogous to the "terminal areas" exemption in section 202(c) of the Act. ${ }^{33}$ The Commission has reiterated this claim since $1948,{ }^{34}$ at one time baldly asserting without qualification that "on analogy with section 202(c) of the act . . . motor transportation which is incidental ... must be limited to a bona fide terminal, as distinguished from line-haul, service."35

Unfortunately, this is an indefensible analogy. Under the Interstate Commerce Act, railroads, water carriers, and freight forwarders are normally not permitted to operate motor vehicles as part of the transportation services they provide. ${ }^{36}$ Section 202(c) creates an exception to this rule by permitting these carriers to operate, directly or by contract with others, "transfer, collection, or delivery services" by motor vehicle "within terminal areas." But this authority is limited to

tion, is that each city have bona fide collection and delivery service to and from its designated airports.")

32. Ibid.

33. 54 Stat. $920:(1940), 49$ O.S.C. \& 302 (c) (1964).

34. Zantop Air Transport, Inc., 102 M.C.C. 457, 461 (1966); Motor Transportation of Property Incidental to Transportation by Aircraft, 95 M.C.C. 71,85 (1964); The Hatom Corp., 91 M.C.C. 725, 730 (1962) (the second Hatom case); Sky Freight Delivery Service, Inc., 47 M.C.C. $229,241-42$ (1947).

35. Second Flatom case, 91 M.C.C. at 730.

36. This is made clear by section 202(a) of the Act, 49 Stat. 543 (1935), 49 U.S.C. § 302 (1964), which places all transportation of persons or property by motor vehicle in interstate commerce under Part II of the Act, subject only to subsequent exemptions in Part II. Thus, for example, a xailroad must fall within an exemption or be certified by the Commission in sorder legally to operate motor vehicle services in interstate commerce. 
transportation by motor vehicle "incidental to transportation or service" provided by railroads, water carriers, or freight forwarders. By contrast, 203(b)(7a) simply exempts transportation "incidental to transportation by aircraft" from Commission economic regulation. The Commission has nowhere explained how the combination of "incidental" and "terminal areas" in 202(c) says no more than "incidental" alone. ${ }^{37}$ The most reasonable interpretation of section $202(\mathrm{c})$ is that "terminal areas" limits the geographic area within which the exempt service may be performed, and "incidental" limits the carrier to the provision of pickup and delivery service to traffic which it transports into or out of the terminal area by $\mathrm{rail}_{\mathrm{x}}$ water, or freight forwarder service. ${ }^{38}$

Statutory implication that 202(c) differs in scope from 203(b)(7a) may be found in Part IV of the Interstate Commerce Act, regulating freight forwarders. Section 418 makes it unlawful for the freight forwarder to operate his own vehicles or to utilize the services of any carriers other than specified common carriers, including "common carriers by motor vehicle engaged in transportation exempted under the provisions of 203(b)(7a) of this Act ...." But an exception to this limitation permits the freight forwarder, "in the performance within terminal areas of transfer, collection, or delivery services," to provide such services himself or to hire anyone to do it for him. ${ }^{30}$ This distinction between service within terminal areas and service provided under the incidental-to-air exemption, strongly suggests that Congress viewed $203(\mathrm{~b})(7 \mathrm{a})$ as meaning more than merely service within terminal areas. ${ }^{40}$

The second section to which the incidental-to-air exemption might be compared is the local cartage exemption (section 203(b)(8)), permit-

37. Since 202(c) was added to the Act in 1940, 54 Stat. 920. (1910), and 203(b)(7a) was added two years previously, 52 Stat. 1029 (1938), if Congress had intended in 1938 that "terminal area" was to be implied in 203(b)(7a), there would have been no ocension to use "terminal area" in 202(c) in 1940.

38. For example, "incidental" in 202(c) limits a rail carricr to the provision of pickup and delivery service within terminal areas to traffic which it, as a rail carrier, moves into or out of the terminal area. Without "incidental" in the section, the railroad would appear to be authorized to provide collection and delivery services in terminal areas for any carriers, not just for itself.

39. 56 Stat. $297-98$ (1942), 49 U.S.C. \$ 1018 (1964).

40. The Commission sought to dismiss the omission of "terminal areas" in secton $203(\mathrm{~b})(7 \mathrm{a})$ by calling it "not significant" and saying that it is "readily conceivable" that the terminal area of an air carrier may be greater than the permissible terminal area of a freight forwarder at the same point. Sky Freight Delivery Services Inc, 47 MLC.C 229, 241-42 (1947). Granting that a size difference in forwarder and air carrier terminal areas may be "readily conceivable," section 418 would still appear to weaken, rather than strengthen, the Commission's argument that 203(b)(7a) implicitly contsins a restriction to terminal area service. 
ting motor vehicles operating in a "zone adjacent to and commercially a part of any ... municipality" to be free of economic regulation under Part II of the Act.41 This exemption defines the limit of the operating rights permitted to firms offering local cartage type services without Commission certification of public convenience and necessity. ${ }^{42}$

The local cartage exemption was part of the original scheme of motor regulation, thus antedating the incidental-to-air exemption by three years. It seems plausible that if Congress had intended the incidental-to-air exemption to mean some specific geographic limitation, paralleling in conception if not in actual size the local cartage exemption, the two exemptions would have used parallel language. But no such parallelism is present: "a zone adjacent to and commercially a part of" a municipality defines a geographic boundary, but "incidental to transportation by aircraft" has no such geographic connotation.

There are thus two statutes chronologically bracketing the incidental-to-air exemption, each of which involves an exemption expressed in geographic terms. The fact that neither of these alternative limitations was used in the incidental-to-air exemption strongly suggests that the exemption was not meant to be defined in terms of some particular, limited area.

A wider interpretation of the exemption is supported by its origin in the Civil Aeronautics Act of 1938.43 Although the history of the exemption itself is concededly obscure, ${ }^{44}$ the Act as a whole was a promotional act, aimed at " $[t]$ he encouragement and development of civil aeronautics" and "[t]he encouragement and development of an air-

41. 49 Stat. 546 (1935); 49 U.S.C. $\& 303(\mathrm{~b})(8)$ (1964). This exemption is also distinguished from the 203(b)(7a) exemption by the existence of a qualifying phrase, inscrted between 203(b)(7a) and 203(b)(8), permitting the Commission to deny the excmption in 203(b)(8) (and all subsequent subsections of 203(b)) whenever this is found to be necessary in order to achieve the goals set forth in Declaration of National Transportation Policy, 54 Stat. 899 (1940).

42. Although $203(\mathrm{~b})(8)$ appears to refer only to interstate and foreign commerce (thus suggesting that the exemption is applicable only to commercial zones extending across state boundaries or serving as foreign trade gateways), the Commission has held that the exemption is applicable to all "purely local intra-terminal motor-carricr transportation," for "[n]o logical reason appears for exempting only those who physically cross a State boundary ...." Commercial Zones and Terminal Areas, 46 M.C.C. 665, 677-78 (1946). In 1953, the Commission concluded that the terminal areas of motor carricrs and frcight forwarders under section 202(c) were to be equated to the commercial zones of the local cartage exemption. Commercial Zones and Terminal Areas, 54 M.C.C. 21, 108-110 (1952). Major cities have uniquely defined commercial zones; for other cities, the permissible distance is graduated with the size of the city-up to five miles from the boundary of the core city for cities with a population of over 100,000. Both the general rules and individually defined zones are found at 49 C.F.R. $\S 170$ (1964).

43. Civil Aeronautics Act of 1938, \& 1107(j), 52 Stat. 1029 (1938).

14. See note 6 supra. 
transportation system properly adapted to the present and future needs of the foreign and domestic commerce of the United States. . . ."45 If the exemption was intended to aid in the promotion and development of air transportation, then it would seem to follow that its evident purpose-freedom from Interstate Commerce Commission regulation of motor transportation of persons and property to and from airports-should be construed widely, not narrowly.

To the extent that a statute, like a woman, may be known by the company it keeps, the exemption ought to mean more than merely an exemption for limited terminal area services. None of the eight exemptions in section 203(b) prior to the incidental-to-air exemption distinguishes between line-haul and terminal services. ${ }^{40}$ Specific uses of vehicles are exempted from regulation, regardless of the length of haul or whether the haul is inter-community or intra-community. No attempt was made to limit hotel bus service to the nearest convenient or practicable common carrier passenger depot, nor to limit the farmer-operated vehicle exemption to hauls between the farm and the nearest commercial center. The rest of section 203(b) thus provides no support for restriction of the incidental-to-air exemption to a limited geographic range. . $^{4 \pi}$ If the interpretation of the exemption is to be colored at all by its context in 203(b), a broad interpretation of "incidental" is necessary.

\section{Economic Characteristics of Air Cargo Pickup and Delivery}

A broad interpretation of the exemption would be more in line with the economic realities of the market for air freight transportation. The limited scope given the exemption by the Commission bears little relation to the actual interactions of air cargo collection and delivery services with air transportation.

45. Sections 2(f), 2(a), 52 Stat. 980 (1938). These provisions are substantially preserved in the Federal Aviation Act of 1958, which supercede the 1938 Act, 72 Stat. 710 (1958), 49 U.S.C. $\$ 1302$ (1964) ("consideration of matters in public interest by Board").

46. 49 Stat. 545 (1935), 49 U.S.C. $\$ 303(\mathrm{~b})$ (1964). The section is entitled "Vehicles excepted from operation of law." It limits the exception to freedom from cconomic regulation, and lists (1) school buses, (2) taxicabs, (3) hotel bus service between hotels and carrier terminals, (4) national park vehicles operated by concessionaires under the control of the federal government, (4a) farmer-operated vchicles moving commodities to and from the farm, (5) vehicles of agricultural marketing cooperatives, (6) vehicles used solely for moving agricultural commodities, (7) newspaper delivery vehicles, and (7a) the incidental-to-air exemption.

47. Chairman Bush, the lone dissenter in the second Zanlop case, also emphrsized the significance of the other exemptions prior to (7a): "It is self-evident that motor car. riers falling within the exceptions of section $203(\mathrm{~b})$... are authorized to perform linehaul transportation in interstate commerce, but such carriers are totally excmpt from the certificate requirements of the Interstate Commerce Act." 102 A.C.C. at 165 (1966). 
Presumably shippers use air cargo only because the advantages of minimal transit time and lower packaging and insurance costs outweigh the lower direct costs of competing modes of surface transportation..$^{48}$ But most consignors and consignees of air cargo do not happen to be located in or next to airports; hence surface transportation is required between the airport and ultimate origins and destinations. This leads to two questions: what surface transportation, and what airport?

If the shipper and receiver of air cargo use their own vehicles to move cargo to and from airports, there is no regulatory problem, for private carriage is not subject to Commission economic regulation. ${ }^{40}$ But only firms with relatively high, steady flows of air cargo are likely to prefer to do their own carriage. Most firms are therefore likely to prefer that plant-to-airport service be provided by others. Regular common carriers, however, are not always able to provide adequate

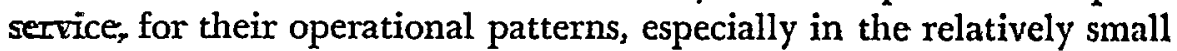
shipments characteristic of air cargo, are not conducive to minimization of plant-to-airport transit time..$^{50}$ Only if they can be induced to provide separate air cargo service, by-passing freight consolidation terminals in order to move shipments directly from shipper to airport, will existing common carriers be able to approach the quality of service that the specialist in air cargo collection and distribution can achieve. And unless the carrier is already certified to serve the whole region about the airport, it will not be in a position to supply such services most efficiently.

To the extent that existing motor common carriers are not geared to: provide accelerated air cargo pickup and delivery service to and from airports, better service may be obtained from the specialist air

48. The demand for air cargo has been broken down into thrce categorics:

(1) Traffic for which air movement is directly price-competitive with surface move. ment. (This is still rare.)

(2) Traffic which is so perishable that it can move only by air.

(3) Emergency traffic where faster air service results in net savings cither by com. manding premium prices for early arrival, or by avoiding continuing, unproduc* tive operating costs due to factors such as parts shortage or break-down.

Carter, Air Cargo Economics, 15 LAw \& Contemp. Pron. 786, 86 (1950).

49. 49 Stat. 546 (1935), 49 U.S.C. \$ 304(a)(3) (1964).

50. Motor common carriers handling less-than-truckload traffic will typically move such shipments through one or two classification terminals. A shipment will be picked ap by a local service vehicle, moved into the terminal, sorted out with other shipments bound for the same general area, moved by line-haul vehicle to the classification terminal for that area, sorted again to the appropriate delivery route, and finally loaded onto the local service vehicle for delivery. For service within the limits of a single classification area, one terminal handling and the line-haul segment of the journey will of course be eliminated. But such service will still be slower than service operating directly from airports to consignors and consignees. 
cargo carrier. ${ }^{51}$ But as discussed above, ${ }^{52}$ the structure of Commission motor carrier regulation is not likely to encourage the emergence of such specialist carriers. The economic patterns of the flow of air cargo to and from individual airports may extend far beyond the existing limits of the incidental-to-air exemption. We may term the geographic area from which air freight may flow into a particular airport the "catchment basin" of that airport. The geographic extent of the catchment basin of any given airport will be economically determined by such factors as the cost of motor transport to and from the airport, the quality and quantity of air cargo service available at the airport, and savings accruing to shipper and receiver from accelerated arrival time of each individual shipment. ${ }^{63}$

Commission attempts to place geographic limits on the incidentalto-air exemption fail to recognize that these factors are not static and do not affect each user of air freight in an identical manner. In the first place, the airlift capacity of flights at a given airport may vary. Few airports generate enough traffic to make economically feasible the designation of the airport as a stop for all-cargo equipment, but almost all airports will provide adequate capacity for the shipper with the occasional 250 pound shipment. Local service airports may be served neither by all-cargo equipment or by the passenger aircraft with cargo holds. Regular shippers of air cargo in cities served by these airports

51. Section 1003(b) of the Federal Aviation Act permits airlines to establish joint rates and through service with other common carriers. Rates established under the authority of this section are subject to review by a joint board composed of C.A.B. and I.C.C. members. While such joint rates and through services are not uncommon in the air cargo industry, they do not provide $a$ full solution to the collection and delivery problem because the route limitations on existing motor carriers make it improbable that any single carrier will have the ronte pattern necessary to permit the most efficient strncturing of collection and delivery services around each airport. 72 Stat. 791 (19j8), 49 U.S.C. § 1483(b) (1964).

52. See notes $2-5$ supra and accompanying text.

53. The concept of an urban area's economic "catchment basin" has been recognized in transportation planning studies.

Even where the centre of the urban region was a single city, and not a conurbation, the urban region would have to take in the whole of the surrounding atchment area, going at least as far out as the "traffic watershed" or limit of car-commuter travel. In a few cases only in this country [Great Britain] there vould be an overlap, representing an equal pull by two or more large centers; but on the whole the "spheres of traffic influence" of the big cities and conurbations are clcarly ascertainable.

REPORT OF THE StEerING GRoup, TRAFFic IN Towns $\$ 46$ (1961) (The "Buchanan Report").

Film Transit, Inc, 98 M.C.C. 145 (1965) suggests the possible scope of the "catchment basin" around the Memphis, Tennessee, airport. The Commission held that Film Transit was operating beyond the 203(b)(7a) exemption when it accepted shipments from an air freight forwarder for transportation by motor vehicle from Mfemphis to Jonesboro 72 miles from Memphis airport), West Helena (82 miles), and Oscoola ( 57 miles), Arkansas; Corinth ( 88 miles) and Iambert ( 84 miles), Mississippi; and Bolivar (68 miles) and Djersburg (78 miles), Tennessee. Id. at 153 . 
may be forced to rely on more distant airports, where higher-capacity equipment is available.

Secondly, some airports may simply be too small to handle the aircraft which the cargo-generating potential of an area might justify. If the local service airport for a community is not authorized to handle four-engined aircraft, air transport for large items must be obtained through a more distant airport.

Thirdly, simple frequency of service at an airport may be significant. A physically adequate airport may be little used: or the airport may be heavily used, but with an insufficient traffic flow to the desired cargo destination to justify through service. A more distant airport may therefore be sought in order to obtain earlier aircraft departure or to obtain through service without the delay of cargo interchange enroute.

All these sets of circumstances often combine to make it impossible to determine, in the abstract, which airport is "the" airport serving a shipper at a particular point. ${ }^{54}$ This will be especially true of shippers located in the Northeast megalopolis, and probably is also true of shippers along the southern edge of the Great lakes and in Southern California. A definition of "incidental" which took into account these characteristics of air cargo collection and distribution would not distinguish between incidental and nonincidental surface transportation according to the distance from the airport to the shipper or receiver, or according to whether the service is intra-community or intercommunity in nature. If a more distant airport is chosen because it (a) is the nearest source of adequate airlift capacity; or (b) permits faster overall service than closer airports, then the connecting surface transport ought to be considered "incidental" to air transport. One principle which follows from this is that if the nearest airport to the shipper is used, whatever the distance involved, the transportation should normally be viewed as "incidental" to transport by air.

54. The shipper thirty miles north of Cheyenne, Wyoming, probably has little choice, but consider the electronics plant located just off the New Jersey Turnpike, opposite Trenton. The nearest airport is the Mercer County Airport, serving Trenton. But there are three other airports-Newark, Kennedy and Philadelphia International-which could rationally be used by a shipper seeking to minimize transit time yet which are all fifty miles or more from our hypothetical shipper. For a similar discussion of how the ICC's limitation restricts the development of air forwarder service sce Snow, Air Freight For: warding: $A$ Legal and Economic Analysis, 32 J. OF AR L. \& CoMm. 485, 487.88, 492.94 (1966).

55. There are no grounds for disagreement with the Commission's requirement that the exemption apply only to cargo having an immediately prior or subsequent movement by air. See 49 C.F.R. $\$ 210.40$ (1966 Supp.). Otherwise all commodities which at one time or another had moved by air might arguably fall within the exemption. 
This interpretation would not keep the Commission out of all adjudication involving the exemption, for at some time there comes a point at which surface transportation is no longer "incidental." Motor transportation from Chicago to New York, followed by air transportation to London, is not "incidental" to the air transportation: were the shipper motivated by the need for faster service he could have found it at Chicago.

One potential objection is raised by this test. It leaves open the possibility that regulated motor common carriers could carry air cargo shipments on an ad hoc basis, charging different (presumably lower) rates for such shipments in comparison with other similar shipments moving exclusively in surface transportation. This mixture of regulated and unregulated traffic may be thought to present undesirable regulatory difficulties. Common carrier rate regulation may be made unduly complex by the simultaneous carriage of regulated and unregulated traffic.

This objection could be avoided by limitation of the exemption to the use of vehicles in air cargo collection and distribution. If the rest of section 203(b) is examined, all of the other subsections exempt, implicitly or explicitly, vehicles when used in prescribed ways.00 If "motor transportation of persons or property" in 203(b)(7a) is interpreted to mean operation of vehicles for the purpose of carrying persons or property incidental to transportation by aircraft, a mixture of regulated and unregulated traffic on the same vehicle will be avoided. This would permit the provision of air cargo collection and distribution services by a regulated motor common carrier, when the carrier assigns vehicles exclusively to that service, instead of combining the air-cargo service with its general, over-the-road line-haul services. ${ }^{57}$

This interpretation of the exemption would make it possible for the airlines, air freight users, and surface carriers of air freight to and from airports to develop collection and distribution services based on the economic characteristics of the catchment basin of each airport,

56. See note 55 supra, and accompanying text. The title of 203(b) is "Vchicles excepted from operation of law." See also Determination of Excmptcd Agricultural Commodities, 52 M.C.C. 511, 523 (1951) ("The . . exemption contained in section 203(b)(6) is directed to the motor rehicles, not to the transportion of agricultural commodities...'”

57. If exempt and non-exempt operations are segregated by vehicles, the Commission can determine without great diffculty whether or not the carrier is using its regulated operations to contribute to the financial viability of its non-regulated operations. This determination will be much more difficult if the Commission must face the diffeulty of allocating vehicle operation costs between exempt and non-cxempt traffic carried on the same vehicle. 
rather than on the Commission's view of what constitutes intracommunity pick-up and delivery service. ${ }^{68}$ Moreover, it is an interpretation which is consistent with some prior statements of the Commission. ${ }^{59}$ Undeveloped ideas in several previous Commission decisions could be used to arrive at the results herein advocated.

In the Sky Freight case, the Commission recognized the reasons behind the use of air transportation instead of surface transportation.

The keynote of air transportation is speed in transit, and substantially higher rates are paid for this type of service. The same factors which prompt the use of air freight service in the first instance would likewise require that such traffic ordinarily move from and to the nearest airport and will tend to minimize the distance involved in "incidental-to-air" motor hauls."0

The Commission should have realized that there are situations in which the factors such as speed "which prompt the use of air freight" might require that the freight move to an airport not the closest to shipper or receiver, and might "require" relatively long motor hauls. ${ }^{01}$

58. The $\mathrm{CAB}$ has indicated that it will authorize extensions of air carricr tariffs covering pickup and delivery services

in the light of whethex the proposed service is truly air cargo pickup and delivery with the use of specialized equipment (vans or straight trucks) and geared to mecting airline schedules and oriented to customer air transportation needs, as distin. guished from line-haul or over-the-road surface transport.

29 Fed. Reg. 6276 (1964). Transportation "geared to meeting airline schedules and ori. ented to customer air transportation needs" may or may not be performed within any particular distance of an airport. See alsa the Flying Tiger case, cited in note 22 supra, involving $\mathrm{CAB}$ authorization of pickup and delivery tariffs covering more than 90 miles.

59. This interpretation of the exemption does no violence to the accepted definition of "incidental"-even though the Commission has sought to justify its own interpretation by recourse to the dictionaries, e.g., in Motor Transportation of Property Incidental to Transportation by Aircraft, 95 M.C.C. 71, 84-85 (1964). "Incidental" may be defined as "occurring or liable to occur in fortuitous or subordinate conjunction with something else." ShOFTER OXFord ENGLISH DicmoNARY 978 (3d ed. 1962). Under the assumption that the advantages realized by the use of air transportation stem from minimization of overall transportation time, the motor service which makes possible the realization of this goal of minimizing time through use of air service would seem to be in subordinate conjunction with the air service. That is, the shipper is concerned with the most readily available air service, and whether he is twenty-five or thirty miles from the airport is more or less a fortuitous circumstance which ought to be irrelevant for purposes of regulation.

60. 47 M.C.C. 229,240 (1947). (Emphasis added.)

61. In a companion case to Sky Freight the Commission discussed the excmption in terms of a distinction between intra-community and inter-community services. It commented that 203(b)(7a) should not be interpreted as applying "to motor carrier operations in the nature of substituted motor-for-air service in lieu of line-haul air carrier operations." Teterboro Motor Transportation, Inc, 47 M.C.C. 247, 255 (1947). This suggests that in formulating its interpretation of $203(\mathrm{~b})(7 \mathrm{a})$, the Commission simply failed to consider the possibility that inter-community motor vehicle service could be anything other than "in lieu of line-haul air carrier operations." The test advocated in this note is, in practical effect, analogous to what the Commission said in Teterboro; onc asks, are motor carrier operations substituting for line-haul air carrier operations? The difference comes from the tempering of the test by the realization that the economic possi. bility of using air transportation instead of motor transportation, rather than the mere 
In the decision establishing the limits of motor carrier and freight forwarder terminal areas under section 202(c), the Commission suggested that service which is "incidental" to another transportation service in the context of the incidental-to-air exemption is not "necessarily" a bona fide intra-community pickup and delivery service within a 202(c) terminal area. ${ }^{62}$ This statement is dictum, because the interpretation of 202(c) rather than 203(b)(7a) was in issue, but it does show that the restrictive definition of "incidental" culminating in the Zantop decision is not the only possible interpretation of the exemption. ${ }^{63}$

There are no grounds for differential interpretations of "incidental." Neither the words of the exemption, nor its statutory context, nor the general goals of the Commission justify the narrow interpretation

physical possibility, should govern the finding that substitution has or has not taken place.

62. Commercial Zones and Terminal Areas, 54 M.C.C. 21, 69-69 (1952). In this case, the freight forwarders sought to argue that "collection and delivery services" (the phrace used in section 202(c) of the Act) beyond commercial zones and terminal areas could be exempted because they were still "incidental" to their long-haul carload movements. The Commission answered by citing 203(b)(7a), which isses "incidental" but not "terminal areas."

In a number of cases ... the question whether particular motor transportation is "incidental" to transportation by aircraft has been found to depend upon whecher the motor transportation was limited to a bona fide terminal service .... Patently; the finding in these cases that transportation within the ... exemption [section 209(b)(7a)] is limited generally to terminal transportation ... does not amount to a finding that every service which is incidental or subordinate to, or the result of, another service is necessarily bona fide collection and delivery service. Certainly, the fact that the forwarders' concentration and distribution servioes are incidental and subordinate to their long-haul ... movements does not mean that they' are bona fide collection and delivery services.

54 M.C.C. 21, $68-69$ (1952). (Emphasis added.)

63. In lieu of specific statutory language, the Commission often relies upon Decharation of National Transportation Policy, 54 Stat. 899 (1910), to justify particular decisions. See Dixie Carriers, Inc. v. United States, 351 U.S. 56 (1950) (the National Transportation Policy is the yardstick by which ICC policy decisions must be measured). In Motor Transportation of Property, 95 M.C.C. 71, 84 (1964), the Commission commented that we believe, having reviewed our past decisions involving section 203(b)(7a), that our prior interpretation is essentially correct ... and is consonant with the aims of the national transportation policy.

The policy statement declares it to be Congressional policy

to provide for fair and impartial regulation ... of transportation subject to the ... Act, ... to recognize and preserve the inherent advantages of cach [mode]; to promote safe, adequate, economical, and efficient service and foster sound ceonomic conditions in transportation and among the several carriers ... to the end of developing ... a national transportation system ....

Declaration of National Transportation Policy, 54 Stat. 899 (19:10). Unless this statement is interpreted to mean that the traffic of Commission-regulated carriers is to be protected come what may -an implausible interpretation in view of the manifold cxemptions contained in Part II of the Act-it gives the Commission no clear guidance in interpreting the exemption. To show inconsistency of a broad interpretation of the excmption with the National Transportation Policy, the Commission would need to show that this interpretation would not "preserve the inherent advantages" of some mode of transportation. or that it would result in unfair or biased regulation, or that it would lead to unsafe or uneconomic operating conditions in transportation. This the Commission has yet to do. 
of "incidental to transportation by aircraft." Whether or not the narrow interpretation of the exemption justifies judicial overruling of the limitation of 203(b)(7a) to intra-community service, ${ }^{04}$ the Commission ought to withdraw the 1964 regulations in favor of a broader interpretation of the exemption consistent with the promotional pur. pose of the Civil Aeronautics Act.

64. In the only case other than Zantop in which specific application of 203(b)(7a) has been challenged, the District Court relied upon the "rational basis" test to uphold Commission application of the 25 mile rule to a particular carrier. Wycoff Co. $v$. United States, 240 F. Supp. 304 (D. Utah 1965). The District Court affirmation of Motor Transportation of Property Incidental to Transportation by Aircraft, 95 M.C.C. 71 (1964), extended only to the power of the Commission to define the scope of the 209(b)(7a) cx. emption in a general rule-making proceeding. The court stated that "inquiry into the substance of the regulations would be premature." Air Dispatch, Inc. v. United States, 287 F. Supp. 450, 453 (E.D. Pa. 1964), aff'd per curiam, 381 U.S. 412 (1965).

Should a case arise in which the Commission unequivocally holds that the analogy of $203(\mathrm{~b})(7 \mathrm{a})$ to the 202 (c) terminal areas exemption requires "incidental-to-air" transportation to be limited to intra-community terminal area service, the Commission ought to be reversed as a matter of law. Otherwise, the outcome depends upon whether the courts permit substitution of judicial interpretation of "incidental to transportation by aircraft" for the Commission's interpretation, or decide that the Commission has broad discretion in applying the exemption, thus limiting the reviewing court to determininf whether the finding "has 'warrant in the record' and a reasonable basis in law," NLRB V. Hearst Publications, Inc, 322 U.S. 111, 131 (1944). Compare Red Ball Motor Freight, Inc. v. Shannon, 377 U.S. 311 (1964) (affirming District Court reversal of Commission finding of illegal for-hire carriage) with United States v. Drum, 368 U.S. 370 (1962) (in a similar situation, reinstating Commission finding of illegal for-hire carriage). The arguments for and against judicial intervention in comparable circumstances are set forth in 4 DAvis, ADMINISTRATIVE LAW 189-240 (1958). 